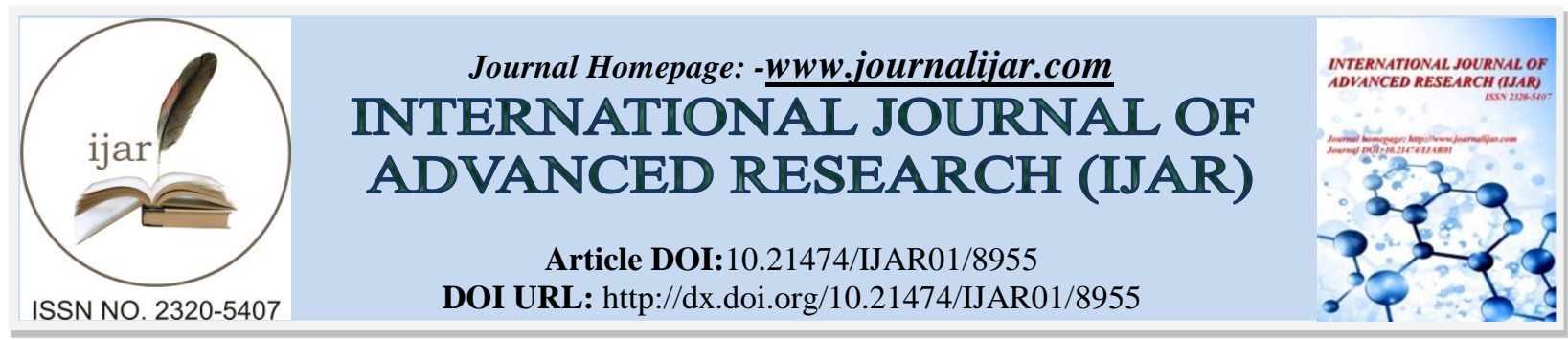

RESEARCH ARTICLE

\title{
POLICY OF GOVERNMENT OF THE REPUBLIC OF INDONESIA IN THE PROTECTION AND CONSERVATION OF REGIONAL LANGUAGES: A LANGUAGE PLANNING STUDY.
}

Nani Darmayanti, Rosaria Mita Amalia, Reiza D. Dienaputra And Eva Tuckytasari Sujatna.

Faculty of Cultural Sciences Universitas Padjadjaran Jalan Raya Bandung Sumedang Km 21 Jatinangor 40353.

\section{Manuscript Info}

Manuscript History

Received: 22 February 2019

Final Accepted: 24 March 2019

Published: April 2019

\section{Key words:-}

Conservation, Language Planning, Policy of Government of Republic of Indonesia, Protection, Regional Languages.

\section{Abstract}

This study analyzes the policies both at the national level, as well as the regional level that has been applied by the Indonesian government in protecting the regional languages in Indonesia. This research uses descriptive qualitative method with literature review technique. This study is specifically restricted to highlight regional language protection policies related to education. The results of research indicate that in terms of regional language protection, both the central government and regional governments have their own government regulations governing the protection of regional languages. Nevertheless, from 34 existing provinces, seven provinces, one city and two districts with regional regulations on regional language protection were identified. All these policies promote regional language protection and preservation through education and teaching in schools, which include (1) Strengthening the Regional Language Curriculum, (2) Increasing Human Resources / Teachers of Regional Languages, and (3) Procurement of Regional Language Teaching Materials. These show that education is still a key factor in the protection and preservation of the regional languages in Indonesia.

Copy Right, IJAR, 2019,. All rights reserved.

\section{Introduction:-}

Republic of Indonesia, abbreviated RI or Indonesia, is a country in Southeast Asia, located on the equator and between the continents of Asia and Australia and between the Pacific Ocean and the Indian Ocean. Because of its location between two continents, and two oceans, it is also referred to as the Archipelago. Indonesia is the largest archipelagic country in the world consisting 17,508 islands. The Republic of Indonesia is also known as a country that has a wealth of culture. This is supported by the number of ethnic groups or tribes in Indonesia that is 1,128 . The whole tribe has different traditions, cultures, and regional languages. (www. indonesia.go.id, 2018).

The national language used by the people of Indonesia is Indonesian language. In addition to the national language, Indonesia is also very rich in regional languages. Data from Institution of Language Development and Maintenance in 2017 states that the number of regional languages that have been inventoried and described as many as 652, not including dialect and sub-dialect (www.badanbahasa.kemdikbud.go.id, 2018).

If dialects and sub-dialect are calculated, according to Population Census in 2010, the number of Indonesian regional languages reaches thousands, which is about 2,500 kinds of languages or almost double the number of 
ethnic groups reaching 1,340 ethnic groups. Among the hundreds of languages in Indonesia, only thirteen languages have speakers over a million, namely Javanese, Batak, Balinese, Bugis, Madurese, Minang, Rejang Lebong, Lampung, Makassar, Banjar, Bima and Sasak. Among the hundreds of languages found in Indonesia, from year to year, the number continues to decrease until endangered, even some are on the way to extinction (Statistic Center, 2010 as cited Ismadi, 2016).

Some of the factors contributing to the declining number of speakers of regional languages, such as Sundanese, are geography-economic and science-technological factors. Urban as the administrative center and the center of economic activity has caused capital to flow profusely, including global capital. The mindset of the people to become economic oriented, including in the field of language. Speakers choose only languages that are considered economically profitable and ignore other languages (including regional languages). The development of science and technology has also shut down some of the vocabulary of regional languages, along with the unrepresented concepts that exist in a word or vice versa.

The results of the Indonesian Language Congress X, recommends the need for the protection of regional languages from threats of extinction with legal umbrella at the regional government level as a whole. In addition, the government also needs to strengthen the role of regional languages in formal education through the provision of curricula that are oriented to regional factual conditions and needs and on non-formal or informal education through community-based language learning

Regional languages are not merely media communications of tribal people. Regional languages are also not just the identity of the differentiation of a tribe with other tribes. Regional languages contain a system of values, knowledge, and worldviews of the living universe of its speaker community. Therefore, regional languages must be continuously used, maintained, and developed.

The brief description above shows that the regional language owned by Indonesia is one of the cultural treasures that must be preserved and protected from extinction. Therefore, this study will examine how (1) which areas in Indonesia have government policies relating to the protection and preservation of local languages? (2) what is the strategy carried out by the central and regional governments in Indonesia for the protection and preservation of regional languages, especially through education channels?

\section{Literature Review}

Language planning is an attempt to influence the functioning, structure, or absorption of one language or type within a community conversation (Kaplan B., Robert, 1997).

Cobarrubias (1983) states that the purpose of language planning depends on the nation or organization, but generally involves making planning decisions and possible changes for the benefit of communication. Planning or updating effective communication can also lead to other social changes such as language movement or assimilation, and provide other motivation to plan language structure, function and absorption.

Chaer (2010) also mentions that language planning is an attempt to guide language development in the direction desired by planners. For example, the planning effort involves making normative spelling, grammatical and dictionary preparations that can be used as a guide for speakers in heterogeneous societies.

In Indonesia, language planning activities have actually been going on, ie from the time of Japan when there was an Indonesian Commission until Alisjahbana published the Indonesian Pembina magazine in 1948. It has even started since Van Ophuisjen compiled the spelling of Malay language in 1901. Followed by the establishment of the Commisie voor de Volkslectuur in 1908 which in 1917 turned into Balai Pustaka (Chaer, 2010).

One form of language planning conducted by the government is the formulation of government policies in relation to the protection and preservation of languages, especially regional languages. In Indonesia, the formulation of policies is regulated based on Law Number 12 Year 2011 on the Establishment of Laws and Regulations. Regards Article 7, Paragraph (1), it is stipulated that the types and hierarchies of the Laws and Regulations consist of: First, the 1945 Constitution of the State of the Republic of Indonesia; Second, the Decree of the People's Consultative Assembly; Third, the Law / Government Regulation in Lieu of Law; Fourth, Government Regulation; Fifth, Presidential Regulation; Sixth, Provincial Regulation; and Seventh, District / City Regulations (Adhi, 2015). 
According to Nurana dan Muta'ali (2010) in Indonesia, the regional authority to draft its own regulation is enacted after the enactment of regional autonomy. This is stated through Law no. 22 of 1999, regional development is implemented through the strengthening of regional autonomy and management of resources that lead to the realization of good governance or good governance. Regional autonomy gives the autonomous regions the right and authority to regulate and manage their own governmental affairs and the interests of the regional people in accordance with the laws and regulations.

In relation to the protection of regional languages in Indonesia Ethnoloque (2012), Sugiono (2108) states that there are 726 regional languages in Indonesia. Some will still develop, but it cannot be denied that most languages will become extinct. According to UNESCO, as stated in the Atlas of the World's Language in Danger of Disappearing, in Indonesia, there are more than 640 regional languages in which there are approximately 154 languages that must be considered, which are around 139 languages endangered and 15 a language that is truly dead. Endangered languages are found in Kalimantan (1 language), Maluku (22 languages), West Papua and Halmahera Islands (67 languages), Sulawesi (36 languages), Sumatra (2 languages), and Timor-Flores and Bima-Sumbawa (11 language). Meanwhile, extinct languages are in Maluku (11 languages), West Papua and Halmahera Islands, Sulawesi, and Sumatra (1 language each) (Wurm (2001).

\section{Methods:-}

The method used in this research is qualitative descriptive. Qualitatively means the data studied and the results of the analysis are obtained from recordings, observations, interviews, or written material, and this data is not numerical. Djojosuroto and Kinayati, (2001). Meanwhile, the descriptive approach is based on facts and it makes data as is without evaluating the wrong or correct data. Sudaryanto (1990).

This research data is a literature study, which consists of all legislation or regulations relating to regional language policies both at the central, and regional levels that explicitly include the preservation of regional languages in the legislation. Data sources in this study are specifically state documents obtained from official government agencies both directly and online, such as the Language Institution, Language Center, City Government, Provincial Government, etc.

The stages of the research contain some levels, first, the researchers inventoried the policies of the Indonesian government at the central level and at the regional level, both provincial, city, and district, which were related to language planning, especially regional languages; second, researchers examined all policies regarding the regional language and focus on the parts relating to policy through the education sector; third, researchers conducted a study of the relationship between central policy and regional policies in the protection of local language through education channels. This policy alignment between the center and the region is important to make the protection of regional languages in Indonesia more comprehensive and systemic.

\section{Results and Discussion:-}

\section{National Policy on Regional Languages}

At the national level, the Republic of Indonesia has three national policies relating to the protection of regional languages. First, the highest policy that Indonesia has in the protection of regional languages is contained in the 1945 Constitution, Article 32 (2) "The State respects and maintains regional languages as national cultural treasures." Secondly, the protection of regional languages is also regulated in Law No. 242009 on Flags, Languages, and Emblems of the Country and National Anthems, which was ratified on July 9, 2009.; Third Government Regulation Number 57 Year 2014 on the Development, Development and Protection of Language and Literature, and Improvement of Indonesian Function.

Law of the Republic of Indonesia Number 24 Year 2009 defines that the regional language is a language used by hereditary by Indonesian citizens in areas in the territory of the Unitary State of the Republic of Indonesia. Thus, the regional language can be symbolized to the identity of the community of the area.

The Law of the Republic of Indonesia Number 24 Year 2009 also mentiones that the policy towards regional languages and literature is directed to three actions, namely development, fostering, and protection of regional languages and literature. Development includes vocabulary enrichment, stabilization and standardization of language systems, as well as development of language barrel. Guidance involves enhancing the quality of language 
use through language learning and linguistic pronunciation to different levels of society. In addition, language coaching is also intended to improve discipline, exemplary, and positive attitude of society to the language. Protection covers efforts to maintain and preserve the language through its research, development, coaching and teaching.

The authority institution of regional language preservation at the national level is Institution for Language Development and Maintenance (Badan Bahasa), which is under the Ministry of Education and Culture of the Republic of Indonesia. This institution is a government agency assigned to handle linguistic and literary matters in Indonesia. The institution has a technical implementation unit (UPT) of 17 language departments and 13 language offices in thirty provinces in Indonesia.

Table 3.1:-National Level Policy in the Regional Language Field

\begin{tabular}{|c|l|}
\hline No & \multicolumn{1}{|c|}{ National Policy } \\
\hline 1. & $\begin{array}{l}\text { 1945 Constitution, Article 32, The State respects and maintains regional languages as a national cultural } \\
\text { treasure }\end{array}$ \\
\hline 2. & Law No. 24 of 2009 on Flags, Languages, and Coat of State and National Anthe \\
\hline 3. & $\begin{array}{l}\text { Government Regulation Number 57 Year 2014 on the Development, Mintenance and Protection of } \\
\text { Language and Literature, and Improvement of Indonesian Functions. }\end{array}$ \\
\hline
\end{tabular}

\section{Regional Policy on Regional Language}

Besides national-level policies undertaken by the central government, in Law Number 24 of 2009 , it is also instructed that regional governments should cooperate with Balai Bahasa or Regional Language Offices in protecting regional languages and literature from extinction. This prompted the regional government to give birth to the Regional Regulation (Perda) on the protection of language in their respective regions. This law can also be a strong foundation in language planning that places regional language as an integral part of regional and national cultural or political strategy.

The results show that from all regions in Indonesia, there are six (6) provinces, one (1) city, and two (2) regencies with special regional regulations on the protection and preservation of regional languages. First, the Government of West Java Province stipulated Perda no. 6 of 1996 on the Preservation, Development and Development of Language, Literature, and Sundanese script that was replaced by law no. 5 of 2003 on the maintenance of Language, Literature, and Regional Literature. West- Java (2014); Second, the Regional Government of South Kalimantan Province has stipulated the Regional Regulation of South Kalimantan Province Number 7 Year 2009 on Maintenance of Language And Literature of the Region. The Regional Regulation shall be stipulated by the Governor of South Kalimantan. South Kalimantan, (2009); Thirdly, the North Sumatera Provincial Government issued Regional Regulation Number 8 Year 2017 on Indonesian Language Preaching, Regional Language Protection, and Regional Literature. North Sumatra (2017); Fourth, Central Java Provincial Government has Regional Regulation no. 9 Year 2012 About Language, Literature, and Javanese Literature. Central-Java (2012); Fifth, Bali Province has Regional Regulation No. 3 of 1992 on Balinese Language, Literature and Literature and is now 26 years old. The Governor has also established the Balinese Language, Literature and Script Board with S.K. Number 179 of 1995, to accommodate activities related to Balinese language, script and literature. Bali, (2003); Sixth, North Maluku Provincial Government issued a Regional Regulation of the Province of North Maluku Number: 9 Year 2009 on Maintenance of Language and Regional Literature. Maluku (2009); Seventh, East Java Province which issued the Governor Regulation No. 19 of 2014 on Regional Language Learning as Regional Content in Regular Schools / Islamic Boarding Schools.

At the city level, the Regional Government (Pemda) of Bandung has given birth to a policy in the form of Regional Regulation (Perda) Bandung No. 09 of 2012 on the Use, Maintenance, and Development of Sundanese Language, Literature and Script (P3BSAS). Bandung (2012); At the district level, Kabupaten Karang Anyar issued a Regional Regulation of Karanganyar Regency Number 2 Year 2013 on the Protection, Development and Development of the Literature, Literature and Literacy of Java which was established on February 6, 2013 and signed by the Karanganyar Regent. Karanganyar, (2013). Besides, there is also Kuningan Regency which issued Regional Regulation of Kuningan Regency Number 6 Year 2006 about Maintenance of Sundanese Language, Literature, and Script. Brass (2006). 
The authority institutions of the protection and preservation of regional languages at the district level are not only conducted by the Office of Language and Language Department but also by the Regional Government Work Units (SKPD) in charge of Education and Culture, and SKPD in charge of Tourism.

Table 3.2:-Regional Level Policy in Regional Language Fields

\begin{tabular}{|r|l|l|}
\hline \multicolumn{1}{|c|}{ No } & \multicolumn{1}{|c|}{ Regional } & \multicolumn{1}{c|}{ Regional Policy } \\
\hline 1. & Province of Bali & $\begin{array}{l}\text { Regional Law No. 3 of 1992 on Balinese Language, Literature } \\
\text { and Script }\end{array}$ \\
\hline 2. & Province of West-Java & $\begin{array}{l}\text { Regional Regulation no. 9 Year 2012 on Protection, } \\
\text { Development, and Language Development, Literature, and } \\
\text { Javanese Literature }\end{array}$ \\
\hline 3. & Province of South Kalimantan & $\begin{array}{l}\text { Regulation No. 7 of 2009 } \\
\text { About Regional Language and Literature. }\end{array}$ \\
\hline 5. & Province of West-Java & $\begin{array}{l}\text { Regulation 14 Year 2014 on Maintenance of Regional } \\
\text { Language, Literature and Script. }\end{array}$ \\
\hline 6. & Province of North Maluku & $\begin{array}{l}\text { Regional Regulation Number 8 Year 2017 on Indonesian } \\
\text { Mainstreaming, Regional Language Protection, and Regional } \\
\text { Literature. }\end{array}$ \\
\hline 7. & Province of East Jawa & $\begin{array}{l}\text { Regional Regulation of North Maluku Province Number: } 9 \\
\text { Year 2009 on Maintenance of Language and Regional } \\
\text { Literature }\end{array}$ \\
\hline 8. & Bandung City & $\begin{array}{l}\text { Governor Regulation No. 19 of 2014 on Regional Language } \\
\text { Learning as Regional Content in Schools / Islamic Boarding } \\
\text { School }\end{array}$ \\
\hline 10. & Regency of Karang Anyar & $\begin{array}{l}\text { Regional Regulation No. 9 of 2012 on the Use, Maintenance } \\
\text { and Development of Sundanese Language, Literature and } \\
\text { Script }\end{array}$ \\
\hline & $\begin{array}{l}\text { Regional Regulation No. 2 of 2013 on the Protection, } \\
\text { Development and Development of Javanese Literature, } \\
\text { Literature and Script }\end{array}$ \\
\hline & $\begin{array}{l}\text { Regional Regulation of Kuningan Regency } \\
\text { Number 6 of 2006 on Maintenance of Sundanese Language, } \\
\text { Literature, and Script }\end{array}$ \\
\hline
\end{tabular}

Strategy for the Protection and Preservation of the Regional Language through Education A. Strengthening the Regional Language Curriculum

All national and regional level policies explicitly state that regional languages should be part of the education curriculum at the primary school level to high school to non-formal education levels. This means that regional language lessons must be one of the regional content subjects in all schools in Indonesia. The regional language, adapted to their respective regions.

Enacting the regional language as a part of the curriculum of this education, for example we can see the Regional Regulation of Bandung Number 9 of 2012 on the Use, Maintenance and Development of Sundanese Language, Literature, in Article 10 paragraph 1 point a states (a) establish and develop Sundanese language, literature and script materials in the regional content curriculum are required at all levels and units of formal and non-formal education.

In addition, there is also in the Provincial Regulation of Central Java No. 9 of 2012 on the Protection, Development and Maintenance of Javanese Literature, Language and Script and the Decree of Central Java Governor (423.5 / 5/2010) on regional content curriculum (Javanese) for primary / junior / senior high school / junior high school / State and Private Islamic Boarding School that explicitly state that Java Regional Content is applied to Junior High School / Islamic Boarding School. 
Regional Regulation No. 7/2009 on Regional Language and Literature published by the regional government of South Kalimantan Article 4 also states that the maintenance of regional languages and literature is carried out through a strategy of realizing a basic and secondary education curriculum for regional language and literature subjects.

The determination of the regional language in this curriculum is in line with what UNESCO recommended in 1951 about the global regulation on the use of the mother tongue as the language of instruction. UNESCO Recommendation 1951 is based on the reasons (1) psychologically the students have emotional attachment to the mother tongue, (2) the mother's sociological language is used productively outside the classroom and in the family, (3) in educative way, the knowledge will be easily digested by the students when presented through a language that has been familiar.

A study also stated that the subjects of regional language at the primary school level is very important in the early level of the introduction of regional languages as a culture of the nation on formal education as well as to be a means in community life that is for communication and ethics in the community polite. (Ayik Rosita and Fifteen Aprila, 2004).

However, there are various obstacles faced in establishing regional languages as part of the education curriculum in Indonesia. The Government, through the Education Act No. 2 of 1989 and the Education Act No. 20 of 2003 prefer the national language as the official language of instruction in the field of national education. Through this national education policy, only the Indonesian language is enriched and strengthened to become the language of science, while the regional language began to be neglected. Regional languages only positioned can be used in the early stages of education and used only when needed.

The position of the regional language in this country is defined with the starting point in terms of the national language, and not in terms of the regional language itself. The national language interest is the basis of thought and the priority. Regional languages are noticed by the government for the benefit of the national language, not for the sake of the regional language itself. Regional languages do not "sit on the same level and stand aloft" with the Indonesian language in respect of awards received from the government. In relation to the Indonesian language, regional languages are treated only as "supporter" who help Indonesians to become wealthier treasures (Purwo, 2000).

In addition to the interesting attraction between Indonesian and regional languages in the Indonesian education curriculum, the regional language setting in the lesson is also hampered by the minimal number of hours for regional language subjects, ie one week only two hours.It also sometimes still offered by a number of schools to reduce the number of hours of regional language lessons (Adhi, 2015).

\section{B. Enhancement of Human Resources / Teachers of the Regional Language}

Regional Regulation of Regency of Kuningan Number 6 Year 2006 concerning Maintenance of Sundanese Language, Lite rature, and Script article 9 states that regional government must provide teachers in the field of language, literature and script of Sundanese and its teaching materials. Thus, Regional Regulation of North Sumatera Number 8 Year 2017 on Indonesian Mainstreaming, Regional Language Protection, and Regional Literature Article 14 states that regional governments are responsible for improving the quality of teachers of Indonesian Language and Regional Language and Literature teachers professionally through certification, as well as Regional Regulations Province of North Maluku Number: 9 of 2009 on Maintenance of Regional Language and Literature Article 8 states that the regional government is responsible for the Provision of regional language and literature staff; the obstacles faced in the provision of teaching staff of this regional language is the limited teachers who have language education background. Many teachers who are nurturing regional language lessons do not have regional language education backgrounds so there is a need to improve the quality of existing regional language teachers and the development of regional language education majors in areas that do not yet have them to produce regional language teachers through formal education (Sari, 2015).

Sudaryat (2006) also revealed that the indicator of regional language teaching problems encountered in West Java is teacher factor related to quality and quantity. Currently the number of Sundanese language teachers in West Java is still small if measured by the ratio between the graduates of UPI (Indonesian Education University) Language Education Department and the number of schools (789 graduates versus 4605 schools). Thus the quality of teachers 
who teach Sundanese language is not optimal because many teachers of Sundanese language is not derived from Sundanese language education graduates. Second, the students' factors related to the attitude of the language they have are very weak. Students' interest to learn Sundanese is generally moderate $(60 \%)$ so that his attitude towards Sundanese became less positive.

\section{Procurement of Regional Language Teaching Materials}

In addition to making the regional language part of the curriculum and provision of teachers, strengthening in the education system for the protection and preservation of languages also explicit about the provision of supporting facilities in the field of regional language and literary education. For example in the law issued by North Sumatra Province No. 8 of 2017 in which it is explained that the Regional Government must hold textbooks, booklets and books of Regional Language and Literature as reference for learners in developing the language skills. Regional governments are obliged to enrich the regional language books and regional literature in the library. In addition, regional governments encourage and facilitate organizations and community institutions in the preservation of Regional Language and Regional Literature.

West Java Provincial Regulation No. 14 Year 2014 on Maintenance of Language, Literature and Regional Script also states that the maintenance of language, literature and regional script is done by providing teaching materials throughout the education lane, as well as reading materials for the library.

Similarly, Regional Regulation No. 2 of 2013 on the Protection, Development and Development of Language, Literature and Javanese Literature Article 14 states that Article 14 Development of Javanese Language in Education Units is done by developing textbooks, booklets, reading books, and Javanese magazines as reference for learners in developing Javanese language, literature and literacy skills.

Procurement of Regional Language Teaching Materials is also not free from obstacles. Regional language teaching materials are still problematic in terms of quantity and quality. Currently the number of regional language textbooks is still limited from the quantity aspect. Regional languages still require supporting facilities such as dictionaries, grammar books, modules, and others to support regional language textbooks. From the aspect of quality also still require improvement. The government needs to be more active in publishing and distributing high quality language, literature, and literacy textbooks.

\section{Conclusion and Recommendation:-}

The results show that in terms of regional language protection, the Government of the Republic of Indonesia, both central government, and regional governments have their own government regulations governing regional language protection. Nevertheless, out of 34 existing provinces, seven provinces, one city and two regencies with regional regulations on regional language protection are identified. All these policies promote regional language protection and preservation through education and teaching in schools, which include (1) Strengthening the Regional Language Curriculum, (2) Increasing Human Resources / Teachers of Regional Languages, and (3) Procurement of Regional Language Teaching Materials. This shows that education is still a key factor in the protection and preservation of the regional language in Indonesia. Nevertheless, various obstacles are still faced by the central and regional governments in realizing regional language protection and preservation policies. Therefore, the synergy of all parties is still needed and still needs to be improved in the protection and preservation of regional languages in Indonesia.

\section{Conflict of interest}

There is no conflict of interest.

\section{Acknowledgments:-}

Thanks to Universitas Padjadjaran for supporting this research through Program Academic Leadership Grant 2017.

\section{References:-}

1. Adhi, S. (2015). "Evaluasi Perda Provinsi Jawa tengah Tentang Bahasa, Sastra, dan Aksara Jawa". Jurnal Ilmiah Ilmu Pemerintahan, 1(2), 15-21. [in Indonesian].

2. Wurm, Stephen A. (ed.). 2001. Atlas of the World's Language in Danger of Disappearing. Paris: UNESCO Publishing. 
3. Ayik Rosita dan Fifteen Aprila. (2004). "Pentingnya Mata Pelajaran Bahasa Daerah dalam Kurikulum Sekolah Dasar dalam Eksistensi Budaya Bangsa". Jurnal Pengembangan Pendidikan, 3(1), 35-43. [in Indonesian].

4. Bali. (2003). Perda Nomor 3 Tahun 1992 Tentang Bahasa, Aksara dan Sastra Bali. [in Indonesian].

5. Purwo, Bambang Kaswanti. (2000). Kebhinekaan Pendidikan dan Bahasa Indonesia. Jakarta: Atmadjaya. [in Indonesian].

6. Chaer, A. dan Agustina, Leoni. (2010). Sosiolinguistik: Perkenalan Awal. Jakarta: Rineka Cipta. [in Indonesian].

7. Cobarrubias, J. (1983). "Ethical Issues in Status Planning." In Progress in Language Planning: International Perspectives. Eds. New York: Mouton Publishers.

8. Djojosuroto, K. dan M.L.A. Sumaryati. (2004). Prinsip-Prinsip Dasar Pedalam Penelitian Bahasa dan Sastra. Bandung: Nuansa. [in Indonesian].

9. Ismadi, H. D. (2016). Kebijakan Perlindungan Bahasa Daerah dalam Perubahan Kebudayaan Indonesia. Retrieved from http://badanbahasa.kemdikbud.go.id/lamanbahasa/artikel/2542/kebijakan-pelindungan-bahasadaerah-dalam-perubahan-kebudayaan-indonesia [in Indonesian].

10. Jawa Barat (2014). Perda No. 14 tahun 2014 tentang pemeliharaan Bahasa, Sastra, dan Aksara Daerah. [in Indonesian].

11. Jawa Tengah. (2012). Perda No. 9 Tahun 2012 Tentang Bahasa, Sastra, dan Aksara Jawa. [in Indonesian].

12. Kalimantan Selatan. (2009). Peraturan Daerah Provinsi Kalimantan Selatan Nomor 7 Tahun 2009 Tentang Pemeliharaan Bahasa dan Sastra Daerah. [in Indonesian].

13. Kaplan B., Robert, and R. B. B. J. (1997). Language Planning from Practice to Theory. Clevedon: Multilingual Matters ltd.

14. Karanganyar. (2013). Peraturan Daerah Kabupaten Karanganyar Nomor 2 Tahun 2013 Tentang Pelindungan, Pembinaan, dan Pengembangan Bahasa, Sastra, dan Aksara Jawa. [in Indonesian].

15. Kementerian Sekretaris Negara. (2018). Geografi Indonesia. Retrieved from http://indonesia.go.id/?page_id=479\# [in Indonesian].

16. Kuningan. (2006). Peraturan Daerah Kabupaten Kuningan Nomor 6 Tahun 2006 tentang Pemeliharaan Bahasa , Sastra, dan Aksara Sunda. [in Indonesian].

17. Maluku. (2009). Peraturan Daerah Propinsi Maluku Utara Nomor 9 tentang Pemeliharaan Bahasa dan Sastra Daerah. [in Indonesian].

18. Nurana, A. Ci., \& Muta'ali, L. (2010). Analisis Dampak Kebijakan Otonomi Daerah terhadap Ketimpangan Perkembangan Wilayah di Kawasan Ciayumajakuning. [in Indonesian].

19. Sari, B. P. (2015). Prosiding Seminar Nasional Bulan Bahasa UNIB 2015. Peran Bahasa Indonesia sebagai Alat Pemersatu Negara Kesatuan Republik Indonesia (NKRI). [in Indonesian]

20. Sudaryanto. (1990). Metode Linguistik ke Arah Memahami Metode Linguistik. Yogyakarta: Gadjah Mada University Press. [in Indonesian]

21. Sugiono. (2018). Perlindungan Bahasa Daerah dalam Kerangka Kebijakan Nasional Kebahasaan. Retrieved from badanbahasa.kemdikbud.go.id/lamanbahasa/content/pelindungan-bahasa-daerah-dalam-kerangkakebijakan-nasional-kebahasaan [in Indonesian].

22. Sumatera Utara (2017). Peraturan Daerah Nomor 8 Tahun 2017 tentang Pengutamaan Bahasa Indonesia, Pelindungan Bahasa Daerah, dan Sastra Daerah. [in Indonesian]

23. Sudaryat. (2006). "Masalah Pengajaran Bahasa Sunda di Sekolah." In Prosiding Konferensi Internasional Budaya Sunda. Bandung: Yayasan Kebudayaan Rancage. 